\title{
Evaluasi Produktivitas Padi Transgenik Rojolele yang Potensial Tahan Penggerek Batang Padi Kuning Scirpophaga incertulas Wlk
}

\section{(Productivity Evaluation of Rojolele Transgenic Rice Lines Resistant to Rice Yellow Stem Borer Scirpophaga incertulas WIk)}

\author{
Ade Nena Nurhasanah, Fatimah Zahra, Amy Estiati, Usyati, Carla Frieda Pantouw, Budi Satrio Maulana, \\ Muhammad Taufik Hidayat, Satya Nugroho*
}

(Diterima September 2019/Disetujui Juni 2020)

\begin{abstract}
ABSTRAK
Penggerek batang padi kuning (PBK, Scirpophaga incertulas WIk) merupakan salah satu hama yang sangat mengganggu pertanaman padi di Indonesia khususnya di sentra padi di Jawa Barat. Karena tidak adanya sumber gen ketahanan di padi, maka perakitan dengan menggunakan teknologi rekayasa genetika merupakan salah satu upaya untuk memperoleh tanaman tahan PBK. Fusi gen cry1B::cry1Aa dari Bacillus thuringiensis telah diintroduksikan ke dalam tanaman padi varietas Rojolele sehingga diperoleh 6 event tanaman padi transgenik tahan PBK (X22, U10, W3,Y7, Q20, dan P8) dan telah diuji ketahanannya di rumah kaca. Selain pengujian ketahanan terhadap PBK, perlu juga dilakukan evaluasi terhadap produktifitas tanaman padi transgenik tersebut. Penelitian ini bertujuan untuk mengevaluasi tingkat produksi keenam event tanaman padi transgenik tersebut yang dilakukan di lapangan uji terbatas di BBPadi, Sukamandi, Subang, Jawa Barat. Penanaman dilakukan mengikuti Pedoman Pelaksanaan Pengujian Keamanan Hayati Produk Bioteknologi Pertanian Hasil Rekayasa Genetik seri Tanaman tahun 1998. Parameter yang diamati adalah karakter agronomi (tinggi tanaman, jumlah anakan per rumpun, dan jumlah malai per rumpun) komponen hasil (jumlah gabah isi per malai, jumlah gabah hampa per malai, panjang malai, dan bobot 1000 butir), dan hasil panen (gabah kering panen dan gabah kering giling). Hasil penelitian menunjukan adanya variasi karakter agronomi di antara ke enam event padi transgenik yang diuji. Event X22, W3, Y7, dan P8 memiliki karakter agronomi, komponen hasil dan hasil panen yang menyerupai varietas Rojolele dan mampu tumbuh dengan baik di kebun percobaan Sukamandi. Adapun event yang dianggap paling menyerupai varietas Rojolele dalam potensi hasil adalah X22 dan W3.
\end{abstract}

Kata kunci: cry1B::cry1Aa, lapangan uji terbatas, padi rojolele, penggerek batang padi kuning, produksi, transgenik

\section{ABSTRACT}

Rice yellow stem borer (YSB, Scirpophaga incertulas WIk) is one of the most damaging rice pests in Indonesia, especially in rice growing centers in West Java. Because there is no source of resistance genes in rice or its close relatives, resistant improvement by genetic engineering is one strategy to obtain resistant rice cultivar. Previously, the crylB::crylAa fusion gene from Bacillus thuringiensis has been introduced into the Rojolele variety to obtain 6 transgenic rice events resistant to YSB (X22, U10, W3, Y7, Q20, and P8) and has been tested for resistance in greenhouses. This study was aimed to evaluate the transgenic rice productivity carried out in a confined field trial in field station belonging to the Center for Rice Research in Sukamandi, Subang, West Java. The procedure for the field testing followed the 1998 Guidelines for Biosafety Testing of Agricultural Biotechnology Products: Plant Seri by the Ministry of Agriculture. The parameters observed were agronomic characters (plant height, number of tillers, and number of panicles) and yield components (number of filled grains per panicle, number of empty grains per panicle, panicle length, and weight of $\mathbf{1 0 0 0}$ grains). The yield was also measured by dry grain yield. The results indicated that the performance were varied among the 6 events tested. Rice events X22, W3, Y7, and P8 showed agronomic characteristics and yield components resembled Rojolele varieties, and performed well under field condition. X22 and W3 showed closest resemblance to Rojolele in terms of yield potential.

Keywords: confined field trial, cryIB::crylAa, production, rice yellow stem borrer, rojolele rice, transgenic

\section{PENDAHULUAN}

Penggerek batang padi kuning (Scirpophaga incertulas WIk) merupakan salah satu hama utama di pertanaman padi daerah sentra produksi padi di

Pusat Penelitian Bioteknologi Lembaga IImu Pengetahuan Indonesia, Jl. Raya Bogor KM 46 Cibinong Bogor 16911

*Penulis Korespondensi: Email: nugroho_satya@yahoo.com
Indonesia, seperti di Jawa Barat. Luas serangan dapat mencapai $141.000 \mathrm{ha} /$ tahun dengan intensitas serangan rata-rata $11 \%$. Hama tersebut dapat menyerang sejak tanaman padi berada di persemaian sampai masa panen (Balai Besar Penelitian Tanaman Padi 2010). Upaya pengendalian hama ini sudah banyak dilakukan oleh petani dengan berbagai cara. Penggunaan insektisida merupakan salah satu cara yang paling sering dilakukan, namun kurang efektif 
karena hama penggerek sendiri hidupnya di dalam batang tanaman padi. Selain itu, penggunaan insektisida dapat menimbulkan efek negatif pada lingkungan. Penggunaan varietas yang tahan terhadap penggerek batang padi kuning merupakan upaya pengendalian yang murah, efektif, dan ramah lingkungan. Akan tetapi, hingga saat ini belum ditemukan varietas padi yang tahan terhadap serangan hama penggerek batang kuning sehingga sulit dilakukan perakitan melalui teknik pemuliaan konvensional.

Perkembangan teknologi rekombinasi DNA memberi peluang untuk dilakukan perakitan varietas yang tahan hama melalui rekayasa genetika. Teknologi perakitan ini memiliki keuntungan dibandingkan dengan perakitan tanaman secara konvensional. Salah satunya adalah bahwa sumber gen yang digunakan dalam proses perakitan sangat luas. Menurut Lemaux (2009) perubahan sifat tanaman dalam upaya untuk meningkatkan ketahanan, produktivitas, dan kualitas tanaman dapat dilakukan dengan menggunakan teknologi rekayasa genetika melalui introduksi atau penyisipan gen tertentu dari organisme lain yang tidak sekerabat.

Pengendalian hama penggerek batang kuning dapat menggunakan protein kristal dari $B$. Thuringiensis yang bersifat toksin bagi serangga dan hama tanaman. Senyawa toksin yang berasal dari kristal protein Cry hanya akan bekerja dan aktif jika bertemu dengan receptor yang tepat di dalam sistem pencernaan serangga dari golongan yang sesuai dengan kelas virulensinya, seperti Cry 1 yang hanya akan bersifat racun pada serangga dari kelompok Lepidoptera (Salm et al. 1994). Ghareyazie et al. (1997) mengintroduksikan $\operatorname{Cry} 1 A(b)$ pada padi aromatik dan menunjukkan perubahan ketahanan terhadap penggerek batang padi merah jambu (Chilo suppressalis) dan penggerek batang padi kuning. Sementara pada padi japonica yang disisipkan gen yang sama menunjukkan ketahanan terhadap hama penggerek batang padi kuning (Wu et al. 1997). Akan tetapi, Ho et al. (2006) mengatakan bahwa terdapat beberapa populasi serangga yang resistensinya telah berkembang terhadap gen cry tunggal. Oleh karena itu, Cohen (2000) menganjurkan untuk mengembangkan tanaman dengan dua toxin $B t$ karena refugia yang dibutuhkan lebih kecil dan memungkinkan untuk dilepas ke lapangan. Kombinasi gen $B t$ yang mengekspresikan fusi protein crylA (b)-crylA (c) telah terbukti efektif pada serangga hama penggerek batang padi kuning tanpa pengurangan produksi ( $\mathrm{Tu}$ et al. 2000). Ho et al. (2006) melaporkan bahwa padi elit Vietnam yang mengekspresikan fusi protein $c r y 1 A b-$ cry1B mampu mematikan $100 \%$ larva instar-1 penggerek batang kuning setelah infestasi selama 1 minggu. Penelitian lain melaporkan bahwa padi transgenik Bt-IR72 secara konsisten tahan terhadap serangan 4 serangga lepidoptera, termasuk penggerak batang kuning lebih dari 3 generasi, baik dalam kondisi serangan alami maupun buatan (Ye et al. 2001).
Introduksi dua gen cry1B-cry1Aa sintetik ke dalam genom tanaman padi varietas Rojolele telah dilaporkan oleh Rahmawati \& Slamet-Loedin (2006) dengan menggunakan media Agrobacterium tumefaciens. Pada penelitian tersebut diperoleh tanaman yang memiliki potensi untuk mengendalikan larva kupu-kupu penggerek batang kuning. Selain itu, Estiati et al. (2007) juga melaporkan keberhasilan menyisipkan gen ketahanan terhadap penggerek batang kuning, cry1B, dengan menggunakan promotor Maize Proteinase Inhibitor (MPI). Kemudian, Usyati et al. (2009) menguji ketahanan tanaman transgenik terhadap penggerek batang kuning, baik tanaman transgenik hasil fusi (gen cry1B-cry1Aa) maupun tanaman transgenik dengan gen cry1B. Hasil pengujian menunjukkan bahwa tanaman transgenik lebih efektif dalam menangkal kerusakan dan mampu menghambat pertumbuhan $S$. Incertulas dengan tingkat ketahanan yang tinggi dibandingkan dengan tanaman non-transgenik.

Selain pengujian pada efektivitas ketahanan atau sifat baru lainnya, pada tanaman padi transgenik perlu juga dilakukan evaluasi pada tingkat produktivitas dan potensi hasil tanaman tersebut. Keberadaan gen yang diintroduksikan diharapkan tidak berpengaruh pada tingkat produksi varietas tanaman yang disisipi sehingga keunggulannya tidak berkurang dan semakin bertambah. Bashir et al. (2004) melaporkan bahwa tanaman transgenik mengandung gen $c r y 1 A c$ dan cry2 $A$ yang memiliki karakter tinggi tanaman dan waktu berbunga yang berbeda dari tanaman kontrol nontransgenik, namun untuk karakter jumlah anakan dan fertilitas bulir menunjukkan perbedaan yang tidak nyata. Sementara itu, hasil penelitian Xu et al. (2018) melaporkan bahwa tanaman padi transgenik yang mengekspresikan fusi protein Cry1Ab/Vip3A memiliki karakter agronomi dan komponen hasil yang tidak berbeda dari tanaman kontrol non-transgenik, XiuShui134.

Penelitian ini bertujuan untuk mengetahui produktivitas galur-galur transgenik potensial tahan penggerek batang padi kuning pembawa fusi gen cry1B::cry1Aa sehingga diperoleh galur yang tahan terhadap penggerak batang padi kuning dan mempunyai tingkat produksi yang sama dengan tetuanya.

\section{METODE PENELITIAN}

Penelitian dilaksanakan di lapangan uji terbatas Balai Besar Penelitian dan Pengembangan Tanaman Padi Sukamandi, Subang, Jawa Barat. Bahan tanam yang digunakan adalah enam galur padi transgenik tahan terhadap penggerek kuning padi yang mengandung fusi gen Cry1B-Cry1Aa, yaitu X22, U10, W3, Y7, Q20, dan P8. Tanaman kontrol yang digunakan sebagai pembanding adalah Rojolele, Rojolele yang diberi insektisida, dan varietas yang rentan terhadap penggerek batang kuning padi, yaitu IR 42 dan IR 64 . Galur padi transgenik tersebut 
merupakan hasil penelitian Pusat Penelitian Bioteknologi-LIPI (Rahmawati \& Slamet-Loedin 2006). Rancangan yang digunakan dalam penelitian ini adalah Rancangan Acak Kelompok (RAK) dengan 10 perlakuan dan 3 ulangan. Perlakuan meliputi X22, U10, W3, Y7, P8, Rojolele, dan Rojolele yang diberi insektisida, IR 42, dan IR 64. Serangan hama pengerek batang padi kuning terjadi secara alami tanpa inokulasi.

Galur padi ditanam dengan menggunakan jarak tanam $25 \times 25 \mathrm{~cm}$ dengan jarak antar-plot 0,5 m. Design plot perlakuan mengikuti aturan penanaman tanaman transgenik di Lapangan Uji Terbatas (LUT) sesuai dengan Pedoman Pelaksanaan Pengujian Keamanan Hayati Produk Bioteknologi Pertanian Hasil Rekayasa Genetik seri Tanaman tahun 1998, dan telah mendapatkan persetujuan pelaksanakan uji oleh Tim Teknis Keamanan Hayati PRG bidang Lingkungan Tanaman. Untuk mencegah perpindahan polen dari galur transgenik ke tanaman padi di sekitar lahan percobaan maka ditanami varietas Rojolele di sekeliling plot percobaan dengan luasan lebih kurang $3 \mathrm{~m}$. Selanjutnya, isolasi waktu digunakan dengan mengatur penanaman padi transgenik 3 minggu lebih akhir dari pertanaman di sekitar lahan percobaan. Selain itu, juga dilakukan pemberian pagar plastik setinggi $2 \mathrm{~m}$ di sekeliling lahan percobaan sebagai isolator fisik dari pertanaman di sekitar lahan percobaan.

Pemupukan diberikan dengan dosis sesuai anjuran untuk lahan persawahan. Plot perlakuan varietas Rojolele aplikasi insektisida yang diberi insektisida berbahan aktif Klorantraniliprole dilakukan secara berkala dengan interval 2 minggu sekali yang dimulai pada minggu kedua setelah tanam sampai 2 minggu menjelang panen. Dosis Klorantraniliprole adalah 0,5 L/ha (konsentrasi $22 \mathrm{cc} / \mathrm{L}$ ).

Pengamatan agronomi dilakukan dengan pengamatan visual pada 10 rumpun tanaman secara acak yang meliputi: tinggi tanaman, jumlah anakan produktif, dan jumlah malai per rumpun. Untuk komponen hasil, variabel yang diamati sebanyak 3 rumpun per plot perlakuan, yang meliputi panjang malai, jumlah bulir per malai, gabah isi, gabah hampa, dan bobot seribu butir (+ kadar air). Hasil panen diukur per luasan plot yang meliputi hasil gabah kering panen (GKP) dan gabah kering giling (GKG).

Data hasil pengamatan dianalisis dengan analisis ragam (ANOVA) dan apabila terdapat perbedaan yang nyata antarperlakuan maka diuji lanjut dengan menggunakan uji wilayah berganda Duncan pada taraf 5\% (Gomez \& Gomez 2010).

\section{HASIL DAN PEMBAHASAN}

\section{Karakter Agronomi}

Karakter agronomi yang diamati pada penelitian ini meliputi tinggi tanaman, jumlah anakan per rumpun, dan jumlah malai per rumpun. Berdasarkan analisis sidik ragam pada karakter agronomi terdapat perbedaan yang nyata pada karakter tinggi tanaman dan jumlah anakan per rumpun. Pada karakter jumlah malai per rumpun tidak terdapat perbedaan yang nyata antara galur-galur transgenik dan Rojolele, baik yang tidak diberi insektisida maupun yang diberi insektisida.

Karakter tinggi tanaman pada Gambar 1 menunjukkan bahwa tinggi tanaman pada setiap galur dan varietas yang diuji berbeda nyata. Tinggi tanaman galur-galur padi transgenik bervariasi, yaitu Galur W3 dan X22 memiliki rata-rata tinggi tanaman yang tidak berbeda nyata dibandingkan dengan Rojolele yang tidak diberi insektisida, sedangkan galur-galur transgenik lainnya terlihat tidak berbeda nyata dibandingkan dengan Rojolele yang diberi insektisida. Meskipun ditransformasi dengan menggunakan konstruksi plasmid yang sama, keenam galur transgenik yang diuji merupakan galur-galur dari event transgenik yang

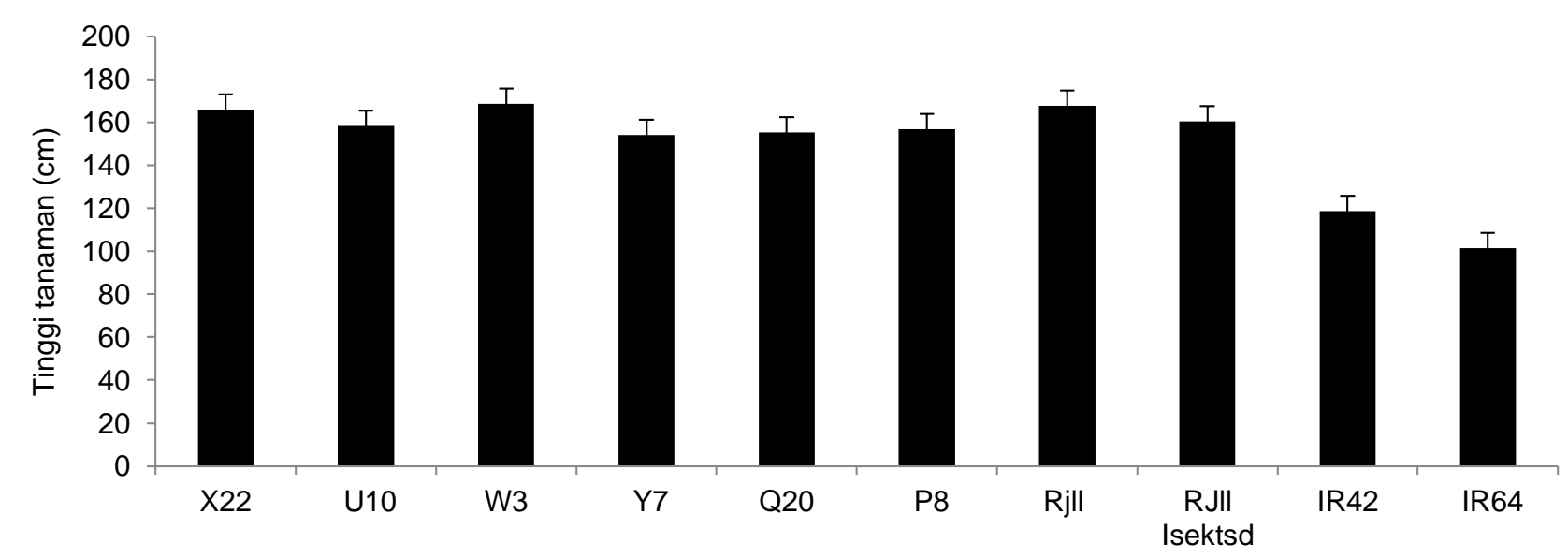

Gambar 1 Rata-rata tinggi tanaman galur-galur padi transgenik fusi cry1B-cry1Aa yang tahan terhadap penggerek batang padi kuning. Event padi transgeni yang diuji (X22, U10, W3, Y7, Q22, P8), Varietas non-transgenik (Rjll), Varietas Non-transgenik dengan perlakukan insektisida (Rjll Isektsd), kontrol agak tahan (IR42), dan kontrol rentan (IR64). 
berbeda sehingga variasi tinggi tanaman yang muncul dapat diduga karena posisi daerah insersi yang berbeda atau dapat pula karena variasi somaclonal. Temuan serupa juga diamati pada berbagai penelitian performa tanaman transgenik di lapang di antaranya penelitian tebu transgenik tahan virus mosaic di China (Yao et al. 2017), tanaman kentang transgenik di Inggris (Dale \& McPartlan 1992), dan penelitian padi transgenik mengoverekspresikan gen Waxy di China (Yu et al. 2009). Menurut Husna \& Ardian (2010), pertumbuhan tinggi tanaman dipengaruhi oleh sifat genetik dan kemampuan tanaman beradaptasi dengan lingkungan tumbuhnya.

Galur W3 memiliki rata-rata tinggi tanaman sekitar $168,67 \mathrm{~cm}$ sebagai galur dengan rata-rata tinggi tanaman tertinggi, sedangkan yang terendah adalah Y7 dengan rata-rata tinggi tanaman sekitar $154,17 \mathrm{~cm}$. Berdasarkan surat Keputusan Menteri Pertanian Republik Indonesia Nomor: 126/Kpts/TP.240/2/2003 mengenai deskripsi varietas Rojolele menyatakan bahwa tinggi tanaman padi varietas Rojolele adalah $144-155 \mathrm{~cm}$.

Karakter jumlah anakan yang terlihat pada Gambar 2 menunjukkan bahwa galur-galur padi transgenik tahan penggerek batang padi kuning menunjukkan perbedaan yang nyata dibandingkan dengan varietas IR 42 dan IR 64, namun beberapa galur transgenik tersebut tidak berbeda nyata dibandingkan dengan rata-rata jumlah anakan varietas Rojolele, baik yang tidak diberi insektisida maupun yang diberi insektisida. Rata-rata jumlah anakan galur-galur transgenik berkisar antara 11-15 anakan, sedangkan rata-rata jumlah anakan varietas Rojolele yang tidak diberi insektisida dan yang diberi insektisida berkisar antara 11-12 anakan. Galur Y7 memiliki rata-rata jumlah anakan yang paling banyak dibandingkan dengan galur transgenik lainnya dan Rojolele, baik yang diberi insektisida maupun yang tidak diberi insektisida.

Pada Gambar 3, hasil pengamatan jumlah malai per rumpun diperoleh rata-rata jumlah malai per rumpun

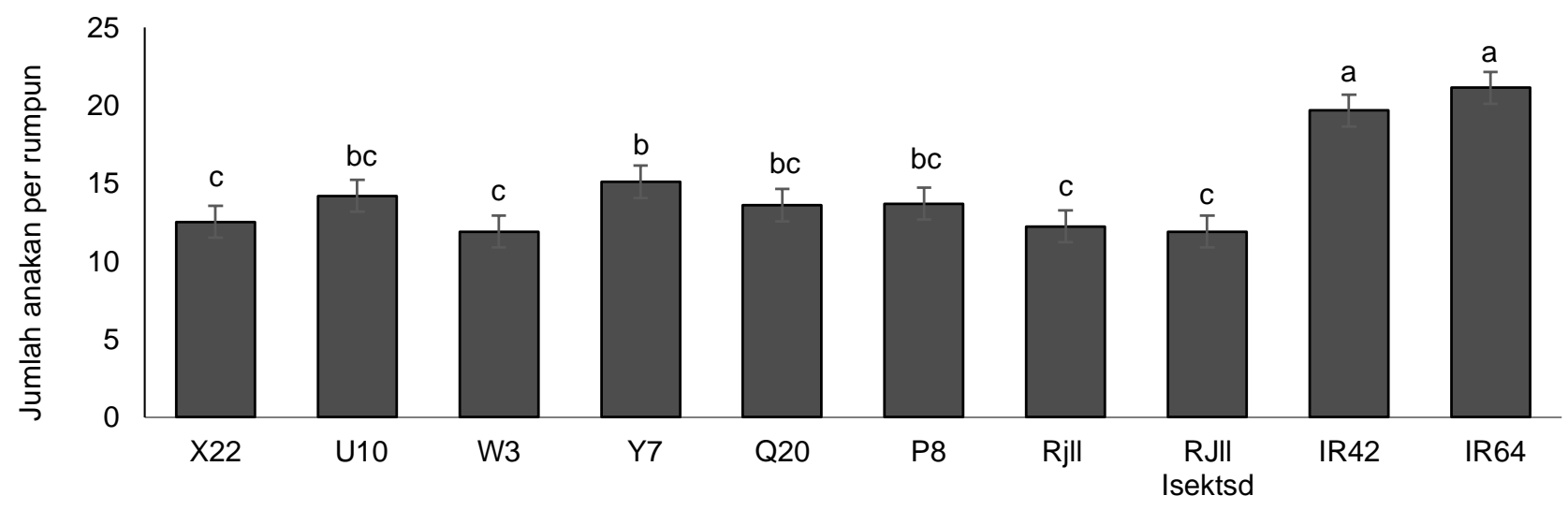

Gambar 2 Rata-rata jumlah anakan per rumpun galur-galur padi transgenik fusi cry1B-cry1Aa yang tahan terhadap penggerek batang padi kuning. Rata-rata jumlah anakan per rumpun galur-galur padi transgenik fusi $c r y 1 B$ cry1Aa yang tahan terhadap penggerek batang padi kuning. Event padi transgeni yang diuji (X22, U10, W3, Y7, Q22, P8), Varietas non-transgenik (Rjll), Varietas non-transgenik dengan perlakukan insektisida (Rjll Isektsd), kontrol agak tahan (IR42), dan kontrol rentan (IR64).

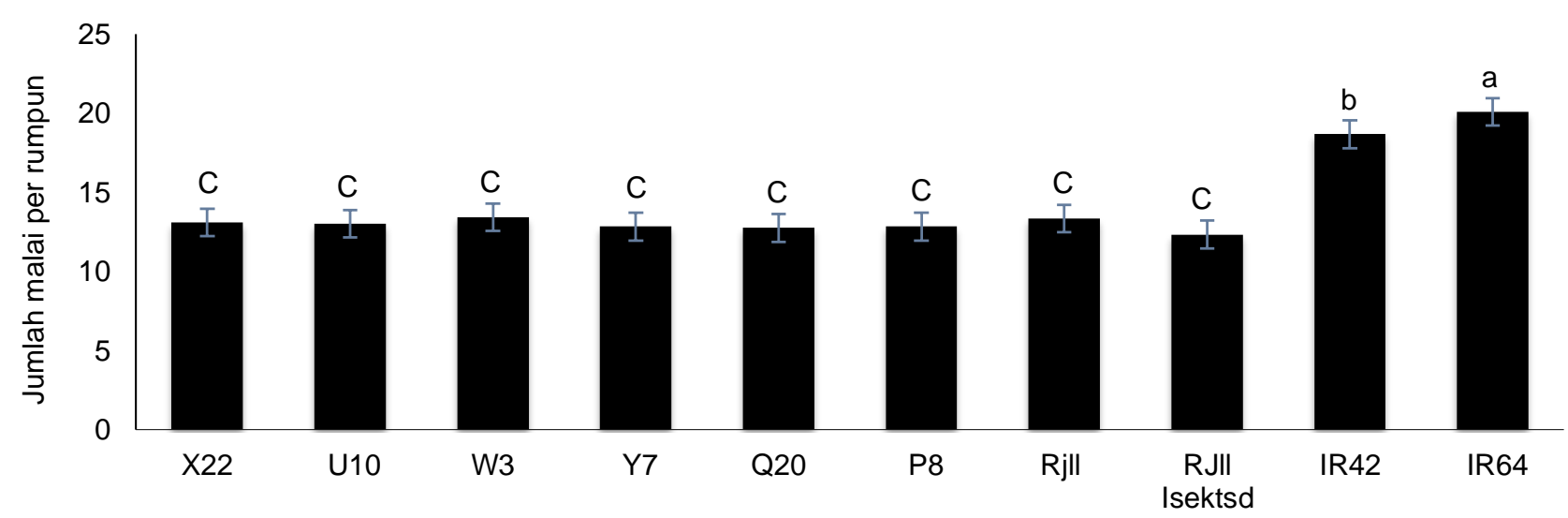

Gambar 3 Rata-rata jumlah malai per rumpun galur-galur padi transgenik fusi cry1B-cry1Aa yang tahan terhadap penggerek batang padi kuning. Event padi transgeni yang diuji (X22, U10, W3, Y7, Q22, P8), Varietas non-transgenik (Rjll), Varietas Non-transgenik dengan perlakukan insektisida (Rjll Isektsd), kontrol agak tahan (IR42), dan kontrol rentan (IR64). 
galur-galur padi transgenik memiliki perbedaan yang nyata dibandingkan dengan varietas IR 42 dan IR 64, namun tidak berbeda nyata dibandingkan dengan Rojolele, baik yang diberi insektisida maupun yang tidak diberi insektisida.

Jumlah malai per rumpun sangat dipengaruhi oleh jumlah anakan per rumpun. Semakin banyak jumlah anakan per rumpun maka potensi untuk memiliki jumlah malai per rumpun semakin besar sehingga pola keduanya akan cenderung sama. Akan tetapi, hasil penelitian ini menunjukkan pola yang berbeda karena jumlah malai per rumpun pada galur-galur padi transgenik tidak sejalan dengan jumlah anakan per rumpun. Hal ini terjadi diduga karena banyak rumpun yang tumbuh setelah melewati fase tertentu sehingga tidak bisa menghasilkan malai. Menurut Wangiyana et al. (2009), jumlah anakan produktif atau anakan yang menghasilkan malai ditentukan oleh jumlah anakan yang tumbuh sebelum mencapai fase premordia.

\section{Komponen Hasil}

Hasil analisis sidik ragam pada komponen hasil yang meliputi panjang malai, jumlah gabah isi per malai, jumlah gabah hampa per malai, dan bobot 1000 butir menunjukkan adanya perbedaan yang nyata untuk semua galur padi transgenik dengan tanaman lain yang diuji. Tanaman padi akan dianggap ideal jika memiliki malai yang panjang dan lebat. Malai yang semakin panjang akan mampu menampung bulir-bulir padi yang lebih banyak. Pada Tabel 1 terlihat bahwa beberapa galur transgenik memiliki malai yang lebih panjang dibandingkan dengan varietas Rojolele, baik yang tidak diberi insektisida maupun yang diberi insektisida. Selain itu, malai beberapa galur transgenik juga lebih panjang dibandingkan dengan varietas IR 42 dan IR 64. Menurut penelitian Wahyuti (2012) bahwa rata-rata panjang malai varietas Rojolele sekitar 31,5 $\mathrm{cm}$, sedangkan dalam penelitian ini, panjang malai galur-galur padi transgenik berkisar antara $29-35 \mathrm{~cm}$. Galur padi transgenik yang memiliki panjang malai tertinggi adalah W3 dan X22 dengan panjang malai 35,67 dan $35,55 \mathrm{~cm}$.
Komponen hasil lainnya yang diamati adalah gabah isi per malai dan gabah hampa per malai. Rata-rata gabah isi per malai pada galur U10 dan Y7 terlihat secara nyata lebih rendah dibandingkan dengan Rojolele, baik yang diberi insektisida maupun yang tidak diberi insektisida, IR 42, dan IR 64, sementara galur-galur padi transgenik lainnya terlihat tidak berbeda nyata dibandingkan dengan Rojolele, baik yang diberi insektisida maupun yang tidak diberi insektisida, IR 42, dan IR 64. Rata-rata jumlah gabah isi per malai galur-galur padi transgenik yang tertinggi adalah galur W3, yaitu sebanyak 124 bulir.

Pada variabel gabah hampa per malai terlihat bahwa galur padi transgenik U10 mempunyai gabah hampa yang nyata lebih tinggi dibandingkan dengan IR 42 dan IR 64, tetapi tidak berbeda nyata dibandingkan dengan Rojolele, baik yang diberi insektisida maupun yang tidak diberi insektisida. Untuk galur-galur padi transgenik lainnya, terlihat gabah hampanya secara nyata lebih rendah dibandingkan dengan Rojolele, baik yang diberi insektisida maupun yang tidak diberi insektisida, tetapi terlihat tidak berbeda nyata dibandingkan dengan IR 42 dan IR 64.

Jumlah gabah per malai dipengaruhi oleh panjang malai. Semakin panjang malai yang terbentuk, semakin besar peluang gabah yang dapat ditampung oleh malai tersebut (Ariwibawa 2012). Selain itu, menurut Wangiyana et al. (2009) anakan yang tumbuh setelah tanaman mencapai fase premordia memiliki sedikit kemungkinan untuk membentuk malai. Jika anakan tersebut membentuk malai terakhir, kemungkinan tidak akan menghasilkan malai yang bulirbulirnya terisi penuh semuanya sehingga memiliki peluang menghasilkan gabah hampa.

Jumlah gabah isi yang terbentuk dalam satu malai sangat bergantung pada proses fotosintesis, translokasi hasil fotosintesis pada saat pengisian biji, dan sifat genetik tanaman padi yang ditanam (Ariwibawa 2012). Husna \& Ardian (2010) juga menyatakan bahwa jumlah gabah isi bergantung pada proses fotosintesis tanaman selama fase reproduksi.

Untuk variabel bobot 1000 butir, galur-galur padi transgenik memiliki bobot yang lebih berat atau lebih

Tabel 1 Rata-rata komponen hasil padi transgenik yang tahan penggerek batang padi kuning dan non-transgenik

\begin{tabular}{|c|c|c|c|c|}
\hline \multirow[b]{2}{*}{ Perlakuan } & \multicolumn{4}{|c|}{ Rata-rata komponen hasil } \\
\hline & $\begin{array}{l}\text { Panjang malai } \\
(\mathrm{cm})\end{array}$ & Gabah isi per malai & $\begin{array}{c}\text { Gabah hampa } \\
\text { per malai }\end{array}$ & $\begin{array}{c}\text { Bobot } 1000 \text { butir } \\
\text { (g) }\end{array}$ \\
\hline $\mathrm{X} 22$ & 35,67 a & $115,33 \mathrm{bcd}$ & $23,60 a b c$ & 32,67 bc \\
\hline U10 & $30,75 \mathrm{bc}$ & $104,67 \mathrm{~cd}$ & $24,60 a b c$ & $31,63^{c}$ \\
\hline W3 & 35,55 a & $123,90 \mathrm{bc}$ & 34,80 a & $32,50 \mathrm{bc}$ \\
\hline Y7 & 29,59 cde & $90,93^{d}$ & $33,27^{a}$ & $30,40^{c}$ \\
\hline Q20 & $29,87 \mathrm{~cd}$ & $91,93^{d}$ & 32,33 a & $31,97 \mathrm{bc}$ \\
\hline P8 & $31,93 b$ & $116,00 \mathrm{bcd}$ & 32,47 a & $31,00^{c}$ \\
\hline Rojolele & 28,11 ef & $120,93 \mathrm{bc}$ & $30,00 a b$ & 46,27 a \\
\hline Rojolele (diaplikasi insektisida) & 28,90 de & $134,33 \mathrm{~b}$ & $21,53 a b c$ & $38,23 \mathrm{~b}$ \\
\hline IR42 & 29,60 cde & 173,87 a & $16,40^{c}$ & $22,93 \mathrm{~d}$ \\
\hline IR64 & $26,66^{f}$ & $122,80 \mathrm{bc}$ & $18,33 \mathrm{bc}$ & $26,03 \mathrm{~cd}$ \\
\hline
\end{tabular}

Keterangan: *) Angka yang diikuti oleh huruf yang sama pada kolom yang sama pada masing-masing perlakuan tidak berbeda nyata pada DMRT taraf 5\%. Event padi transgeni yang diuji (X22, U10, W3, Y7, Q22, P8), Varietas non-transgenik (Rjll), Varietas non-transgenik dengan perlakukan insektisida (Rojolele diaplikasi insektisida), kontrol agak tahan (IR42), dan kontrol rentan (IR64). 
tinggi dibandingkan dengan IR 42 dan IR 64, namun lebih ringan dibandingkan dengan Rojolele, baik yang diberi insektisida maupun yang tidak diberi insektisida. Galur-galur padi transgenik tersebut memiliki kisaran bobot 1000 butir antara 30-32 g, sedangkan Rojolele yang tidak diberi insektisida dan yang diberi insektisida memiliki rata-rata bobot gabah 1000 butir yang lebih tinggi dengan kisaran antara 33,8-46,27 g. Pada deskripsi varietas, bobot 1000 butir gabah varietas Rojolele adalah sebesar $32 \mathrm{~g}$. Galur transgenik dengan bobot 1000 butir gabah tertinggi adalah X22, W3, dan Q20, yaitu seberat $32 \mathrm{~g}$.

\section{Hasil Panen}

Hasil penelitian pada Tabel 2 menunjukkan bahwa secara keseluruhan hasil panen, baik gabah kering panen maupun gabah kering giling, galur-galur padi transgenik dan Rojolele memiliki rata-rata hasil panen yang lebih rendah dibandingkan dengan IR 42 dan IR 64. Galur X22 dan W3 memiliki rata-rata hasil panen, baik gabah kering panen maupun gabah kering giling, yang tidak berbeda nyata dibandingkan dengan Rojolele yang tidak diberi insektisida, sedangkan galur lainnya berbeda nyata dibandingkan dengan Rojolele, baik yang tidak diberi insektisida maupun yang diberi insektisida. Hal ini menunjukkan bahwa galur X22 dan W3 memiliki kemampuan untuk menghasilkan gabah kering panen (GKP) dan gabah kering giling (GKG) yang sama dengan Rojolele yang tidak diberi insektisida.

\section{KESIMPULAN}

Berdasarkan hasil penelitian ini dapat disimpulkan bahwa keenam galur padi transgenik yang diuji memiliki karakter agronomi dan komponen hasil yang berbeda-beda. Galur-galur X22, W3, Y7, dan P8 memiliki karakter agronomi, komponen hasil, dan hasil panen yang menyerupai varietas Rojolele dan mampu tumbuh dengan baik di kebun percobaan Sukamandi.
Galur X22 dan W3, berdasarkan karakter agronomi dan komponen hasil, memiliki kesamaan terbaik dengan Rojolele non-transgenik. Pada variabel hasil panen, X22 dan W3 juga memiliki kemampuan menghasilkan gabah kering panen (GKP) dan gabah kering giling (GKG) yang tidak berbeda nyata dibandingkan dengan Rojolele yang tidak diberi insektisida. Hal ini menunjukkan potensi hasil dari kedua galur tersebut sama dengan Rojolele sebagai tetuanya.

\section{UCAPAN TERIMA KASIH}

Penelitian ini didanai oleh DIPA PN 2012-2013 bekerja sama dengan Balai Besar Penelitian Tanaman Padi, Badan Penelitian dan Pengembangan Pertanian, Kementerian Pertanian Republik Indonesia.

\section{DAFTAR PUSTAKA}

Aribawa 2012. Pengaruh sistem tanam terhadap peningkatan produktivitas padi di lahan sawah dataran tinggi beriklim basah. Denpasar (ID): Balai Pengkajian Teknologi Pertanian (BPTP) Bali.

Balai Besar Penelitian Tanaman Padi. 2010. Mengendalikan hama penggerek batang kuning dengan perangkap berferomon. Informasi Ringkas [Internet]. [diunduh 2017 Agustus 10]. Tersedia http://pustaka.litbang.deptan.go.id/bppi/lengkap/bp p10050.pdf

Bashir K, Tayyab H, Tahira F, Zakia L, Syed AM, Riazuddin S. 2004. Field evaluation and risk assessment of transgenic indica basmati rice. Molecular Breeding. 13: 301-312. https:// doi.org/10.1023/B:MOLB.0000034078.54872.25

Cohen MB. 2000. Bt rice : Practical steps to sustainable use. International Rice Research Notes. 25(2): 410.

Tabel 2 Rata-rata hasil panen padi transgenik yang tahan terhadap penggerek batang padi kuning dan non-transgenik

\begin{tabular}{lrr}
\hline & \multirow{2}{*}{ Perlakuan } & \multicolumn{2}{c}{ Rata-rata hasil panen (ton/ha) ${ }^{*}$} \\
\cline { 2 - 3 } X22 & Gabah kering panen (GKP) & Gabah kering giling (GKG) \\
U10 & $2,82^{\mathrm{c}}$ & $2,74^{\mathrm{c}}{ }^{\mathrm{e}}$ \\
W3 & $1,60^{\mathrm{e}}$ & $1,55^{\mathrm{e}}$ \\
Y7 & $2,41^{\mathrm{cd}} \mathrm{2d}$ & $1,36^{\mathrm{cd}}$ \\
Q20 & $1,94^{\mathrm{de}}$ & $1,84^{\mathrm{de}}$ \\
P8 & $1,90^{\mathrm{de}}$ & $1,84^{\mathrm{de}}$ \\
Rojolele & $1,88^{\mathrm{de}}$ & $2,73^{\mathrm{c}}$ \\
Rojolele (diaplikasi insektisida) & $2,76^{\mathrm{c}}$ & $3,51^{\mathrm{b}}$ \\
IR42 & $3,56^{\mathrm{b}}$ & $6,66^{\mathrm{a}}$
\end{tabular}

Keterangan: *) Angka yang diikuti oleh huruf yang sama pada kolom yang sama pada masing-masing perlakuan tidak berbeda nyata pada DMRT taraf 5\%. Event padi transgeni yang diuji (X22, U10, W3, Y7, Q22, P8), Varietas non-transgenik (Rojolele), Varietas Non-transgenik dengan perlakukan insektisida (Rojolele diaplikasi insektisida), kontrol agak tahan (IR42), dan kontrol rentan (IR64). 
Dale PJ, McPartlan HC. 1992. Field performance of transgenic potato plants compared with controls regenerated from tuber discs and shoot cuttings. Theoretical and Applied Genetics. 84: 585-591. https://doi.org/10.1007/BF00224156

Kementerian Pertanian.1998. Pedoman pelaksanaan pengujian keamanan hayati produk bioteknologi pertanian hasil rekayasa genetik seri ikan, seri tanaman. Jakarta (ID).

Estiati A, Rahmawati S, Astuti D, Loedin IHS. 2007. Agrobacterium-mediated transformation of javanica rice plants with cry $1 B$ gene under the control of wound-inducible gene promoter. Annales Bogoriensis. 11(1): 1-7.

Ghareyazie B, Alinia F, Menguito CA, Rubia LG, De Palma JM, Liwanag EAa, Cohen MB, Khush GS, Bennet J. 1997. Enhanced resistance to two stem borer in an aromatic rice containing a synthetic cry IA(b) gene. Molecular Breeding. 3: 401-414. https://doi.org/10.1023/A:1009695324100

Gomez AK, Gomez AA. 2010. Prosedur Statistika untuk Penelitian Pertanian Edisi Kedua. Penerjemah: Endang Sjamsuddin dan Justika S. Baharsjah. Jakarta (ID): Universitas Indonesia Press.

Ho HN, Niranjan B, Norman O, Karabi D, Roger F, Swapan KD. 2006. Translation fusion hybrid genes confer resistance against yellow stem borer in transgenic elite vietnamase rice (L.) cultivar. Crops Scince. 46: 781-789. https://doi.org/10.2135/ cropsci2005.06-0111

Husna Y, Ardian. 2010.Pengaruh penggunaan jarak tanam terhadap pertumbuhan dan produksi padi sawah (Oryza sativa L.) varietas IR 42 dengan metode SRI (System of Rice Intensification). SAGU. $9(1): 21-27$.

Lemaux PG. 2006. Introduction to genetic modification. Agricultural Biotechnology in Californiaseries. 8178. California (US): ANR Publication.

Rahmawati S, Slamet-Loedin IH. 2006. Intriduksi gen cry1B-cry1Aa ke dalam genom tanaman cv. Rojolele menggunakan transformasi Agrobacterium. Hayati. 13: 19-25. https://doi.org/ 10.1016/S1978-3019(16)30374-6

Salm VT, Bosch D, Honee G, Feng I, Munsterman E, Bakker P, Stiekema WJ, Visser B. 1994. Insect resistant of transgenic plants that express modified Cry $1 \mathrm{~A}(\mathrm{~b})$ and Cry $1 \mathrm{C}$ genes : a resistant management strategy. Plant Molecular Biology. 26: 51-59. https://doi.org/10.1007/BF00039519
Tu J, Zhang G, Datta K, Xu C, He Y, Zhang Q, Khush GS, Datta SK. 2000. Field performance of transgenic elite commercial hybrid rice expressing Bacillus thuringiensis $\delta$-endotoxin. Nature Biotechnology. 18: 1101-1104. https://doi.org/ $10.1038 / 80310$

Usyati N, Damayanti B, Syafrida W, Purnama $H$, Loedin IHS. 2009. Keefektivan padi transgenik terhadap hama penggerek batang padi kuning Scirpophaga incertulas (Walker) (Lepidoptera : Crambidae). Jurnal Entomologi Indonesia. 6(1): 3041. https://doi.org/10.5994/jei.6.1.30

Wahyuti TB. 2012. Hubungan karakter morfologi dan fisiologi dengan hasil dan upaya meningkatkan hasil padi varietas unggul. [Disertasi]. Bogor (ID): Institut Pertanian Bogor.

Wangiyana W, Laiwan Z, Sanisah. 2009. Pertumbuhan dan Hasil Tanaman Padi Varietas Ciherang dengan Teknik Budidaya "SRI (system of rice intensification)" pada Berbagai Umur dan Jumlah Bibit per Lubang Tanam. Crop Agro. 2(1): 70-78.

Wu C, Y Fan, C Zhang, N Oliva, SK Datta. 1997. Transgenic fertile japonica rice plant expression a modified crylA(b) gene resistant to yellow stem borer. Plant Cell Report. 17: 129-132. https://doi.org/10.1007/s002990050365

Xu C, Cheng J, Lin H, Lin C, Gao J, Shen Z. 2018. Characterization of transgenic rice expressing fusion protein Cry1Ab/Vip3A for insect resistance. Scientific Reports. 8: 1-8. https://doi.org/10.1038/ s41598-018-34104-4

Yao W, Ruan M, Qin L, Yang C, Chen R, Chen B Zhang M. 2017. Field Performance of Transgenic Sugarcane Lines Resistant to Sugarcane Mosaic Virus. Frontier in Plant Science. 104(8): 1-9. https:// doi.org/10.3389/fpls.2017.00104

Ye GY, Jumin T, Cui H, Datta K, Datta SK. 2001. Transgenic IR72 with fused Bt gene cry $1 \mathrm{~A}(\mathrm{~b}) /$ cry $1 \mathrm{~A}(\mathrm{c})$ from Bacillus thuringiensis is resistant againt four lepidoptera species under field condition. Plant Biotechnol. 18: 125-133. https://doi.org/10.5511/ plantbiotechnology.18.125

Yu H, Liu Q, XU L, Lu M, Cai X, Gong Z, Yi C , Wang Z, Gu M. 2009. Breeding and Field Performance of Novel Soft and Waxy Transgenic Rice Lines Without Selectable Marker. Acta Agronomica Sinica. 35(6): 967-973. https://doi.org/ $10.1016 / \mathrm{S} 1875-2780(08) 60084-X$ 